\title{
A Business Model Innovation Methodology for Established Organizations: Systematic Theory Validation
}

\author{
Michael Lang \\ Department of Management, Faculty of Business and Economics, Mendel University \\ Brno, Zemědělská 1, 61300 Brno, Czech Republic \\ E-mail: mail@michaellang.info
}

Received: August 30, 2020 Accepted: October 26, 2020 Published: November 10, 2020

doi:10.5296/jebi.v7i2.17605 URL: https://doi.org/10.5296/jebi.v7i2.17605

\begin{abstract}
The goal of this paper is to validate a business model methodology in practice. The goal of the business model methodology is to generate new business models with disruptive potential by overcoming the blindness of organizations mindset. In total nine focus group workshops in automotive, home appliances and high-tech industry with defined tool set and methods are processed. By conducting the workshops in practice several methods of the theory could be validated and points of improvement identified.

Among other findings, the applied methods of the new business model methodology are successful in identifying relevant levers for disruption. Even several starting points for new disruptive business models are found.

In addition, the workshop participants' feedback implicate that in contrast to other studies aligning the process of overcoming the organizational mindset within the business model innovation process, is more effective than implementing a prepending phase to it.

In summary, the present research aims at contributing to the research gap within science regarding the consideration of organizational mindset within business model innovation. Conclusively, it becomes obvious that, while this research delivers a methodology, which serves as an indication on how to close the research gap of acknowledging organizational mindset within the beginning of the innovation process, further significant research gaps remain to be investigated. Thus, two research gaps are identified. First, the later stages of the business model innovation need further investigation. Secondly, the challenge of organizational mindset in the later steps have also not received sufficient scientific interest as yet.
\end{abstract}


Keywords: systematic theory validation, business model, business innovation, organizational mindset, organizational mindset, focus group workshop

\section{Introduction}

\subsection{The Challenge of Disruptive Thinking and New Technologies}

"One secret to maintaining a thriving business is recognizing when it needs a fundamental change." Johnson, Christensen, and Kagermann (2008, p. 50)

Netflix increased its market value more than 50 billion dollars this year and is now more worth than the established company Disney (Shapiro, 2020). Since its foundation in 1997 by Reed Hastings and Marc Randolph, the company started offering online movie rentals and replaced Blockbuster (Shapiro, 2020). In 2007, Netflix switched completely its business model to a digital streaming service, which allows members instantly watch movies on their personal computers (UȚ̆̌, 2020). In reference to UȚĂ (2020), Netflix changed how and what people watch. They disrupted the cable TV industry through technological innovations like digital streaming and machine learning.

But this is just one example of a challenger threatening a whole industry with a so-called disruptive business model. In accordance to Rogers (2016, p. 77) these asymmetric competitors "offer similar value propositions to customers, but their business models are not the same." Also Spotify with its audio streaming offerings put the music industry under pressure and Kodak got kicked off the market by competitors who, in contrast to them applied business models around digital photography even through Kodak held all relevant patents (Matzler et. al., 2016, pp. 76-77; Gassmann, Frankenberger, and Csik, 2017, p. 13). These challengers are called Disruptors, who attack established organizations with different strategies and thereby destroy whole industries. In all of the cases businesses of incumbents got threatened significantly to the point of total destruction.

\subsection{The Challenge for Business Model Innovation for Established Organizations}

No industry will remain unaffected by disruptive strategies, which are enabled by mega-trends, new technologies and changing customer behaviors (Csik, 2014, p. 1). The automotive industry is one sector, which feels competitive pressure posed by disruptive threats, extremely, like the new players Tesla and Google Car currently reveal. It is not only digitalization, which has empowered new players to enter markets, even with relatively little investments, but also business models with great impact for incumbents. Nevertheless, disruption is going far beyond digitalization and technology advance. In reference to Rogers (2016, pp. 1-18) disruption is breaking up the balance of power of existing industry structures and smashes their established beliefs.

The Venture Capital Scene has even defined disruptive potential as one major criterion for startups (Matzler et. al., 2016, p. 75). According to Moreno (2017), these startups have the advantage of being ,smaller, nimbler out- fits are focused on continuously innovating from within, and these emerging companies' rates of innovation are outpacing the rates of established companies. "This shows clearly, how tempting business models are, which attack 
existing markets of incumbents. But how can established organizations deal with these coming disruptive threats? John Chambers, executive chairman and former CEO of Cisco declares the ubiquitous apparent maxim of today's competitive environment: Disrupt, or you will get disrupted (Holmes, 2017). In reference to Moreno (2017), a Forbes survey of 400 top global executives also reveals " $70 \%$ of survey respondents say they are extremely concerned or somewhat concerned as to whether their company will still be relevant and competitive in two years. "Even "well-managed companies that have their competitive antennae up, listen astutely to their customers, invest aggressively in new technologies, [...] yet still lose market dominance.

For incumbents, Chamber's forecast is not very encouraging, yet it clarifies the urgency for incumbents to tackle potential disruption. Companies have to actively participate in creating a future by establishing disrupting business models themselves even if this means to disrupt their own business in order to be a creator of the future. In a larger sense, disruption is not only a way of defending the incumbent company from potential outside disruptive threat but also to reinvent the organization in order to create successful business model innovation. Incumbents themselves need to take disruptive methodologies.

In today's digital world, many organizations struggle to achieve their growth and earnings targets (Sniukas et al., 2016, p. 5). One possible motive is that established organizations are challenged by new market players who have better answers to a volatile, uncertain, complex, and ambiguous world (VUCA World) (Bennett\&Lemoine, 2017).

\subsection{The Need of a Business Model Innovation Methodology for Established Organizations}

In reference to Rogers (2016, pp. 1-18) and Wördenweber (2012, p.12), there is a lack of understanding how the mindset of organizations affects how it handles business model innovation. In contrast to that, Franke\&Zu Knyphausen-Aufsess (2014, p. 35) and Bettis\&Prahalad (1995, p. 7) highlight that there is evidence that overcoming the organization's present culture is a major challenge in business model innovation. However, recognizing the urgency and actually dealing with disruption is something different. The research of Lang (2020, pp. 435-449) underlined that current theoretical methods for business model innovation don't deliver the desired answers to the ongoing changes in a disruptive business environment. For this reason, the research goal is to present a business model innovation methodologies which integrates the overcoming of incumbents' organizations mindset and to validate it in practice by focus group workshops in different industries.

More precisely, the following questions shall be answered through a systematic literature review:

- What are the characteristics of a business model innovation methodology which supports the overcoming of organizational mindset of incumbant companies?

- How can the business model innovation methodology can be validated for usability in practice?

- What are the key learnings of the theory validation and how does the model innovation methodology needs to be refined to cover the key learnings? 


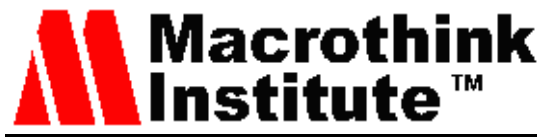

- What are recommended further investigations on the topic business model innovation and organizational mindset for future research?

\section{Method}

2.1 Defining Business Model, Business Model Innovation, Organizational Mindset and Business Model Innovation Methodology

This section covers the theoretical basis in form of definitions, business model, business model innovation theory itself as well as the current research state of organizational mindset.

\subsubsection{Business Model}

Since 1995, business models have gained increasing attention from academics and scientists. Reviewing current literature reveals that, while earlier research focused on the definition of business models, more recent studies shift towards the design and implementation of business models (Stampfl, 2016, pp. 24-25). In the beginning, authors assumed that strategy and business model represent identical concepts in the field of strategy research. Nowadays, literature considers them as different, yet related concepts (Stampfl, 2016, pp. 30-31). Magretta (2002, p. 9) considers a business model a system, which describes how different elements of the business fit together, without including competition as a critical dimension. Strategy on the other hand, explains what a company does different and, therefore, better than its competitors. Hence, strategy focuses on a company's competitive position, while the business model translates the strategy into concrete activities (Stampfl, 2016, pp. 30-31; Csik, 2014, p. 20; Magretta, 2002, pp. 3-4). Osterwalder and Pigneur (2010, p. 15) agree that the business model implements the strategy "through organizational structures, processes and systems".

Despite this common understanding, no universally valid definition, which science agrees upon, can be found (Shafer, Smith, \& Linder, 2005, p. 199; Csik, 2014, p. 20; Chesbrough \& Rosenbloom, n. d., p. 6). However, definitions generally focus on the elements needed to create and capture value. Magretta (2002, p. 2), for example, states that "a good business model answers Peter Drucker's age-old questions: Who is the customer? And what does the customer value? It also answers the fundamental questions every manager must ask: How do we make money in this business? What is the underlying economic logic that explains how we can deliver value to customers at an appropriate cost?'. Mitchell and Coles (2003, p. 16; 2004, p. 17) describe a business model as "'who', 'what', 'when', 'where', 'why', 'how', and 'how much' an organization uses to provide its goods and services and develop resources to continue its efforts." Osterwalder and Pigneur (2010, p. 14) agree that a business model combines several elements to organize, create, deliver and capture value.

Chesbrough and Rosenbloom (n.d., pp. 6-7) also define business models as the unique combination of elements companies create value with: "a business model is a description of how your company intends to create value in the marketplace. It includes that unique combination of products, services, image, and distribution that your company carries forward" but further include "the underlying organization of people, and the operational infrastructure that they use to accomplish their work". Amit\&Zott (2001, p. 493) further add 
that the business model acts as "an important locus of innovation" and is "a crucial source of value creation for the firm and its suppliers, partners and customers" and, thus, emphasize the importance of business models in the context of innovation.

Correlating to the ontology of Osterwalder (2004, p. 42), which describes the "four main areas that constitute the essential business model issues of a company" as product, customer interface, infrastructure management and financial aspects, most relevant literature definitions name

- The Value Proposition: What is offered to the customer?

- The Customer Segment: Who is the customer?

- The Value Chain: How is this value proposition created and distributed to the customer?

- The Revenue Model: How does the business model generate revenue and why is it profitable?

as the main elements of a business model (Csik, 2014, pp. 22-25; Stampfl, 2016, p. 33). Reducing a business model to these four elements facilitates its practical applicability. Simultaneously, this presents a concept, which is complex enough to provide a holistic picture of the business model architecture, as it covers all factors from inside and outside the company (Gassmann, Frankenberger \& Csik, n.d., pp. 1-2).

For this paper, in accordance with the elaborated definitions, a business model translates the business strategy into concrete activities, structures and processes. A business model also creates, captures and delivers value to a certain customer segment. Therefore, it acts as a basis, lever and source for innovation. It thus consists of the following elements: value proposition, customer segment, value chain and revenue model.

\subsubsection{Business Model Innovation}

For quite a long time, the most common types of innovation in academic literature and in managerial practice were product/service, performance, process, organizational, social or market innovations. In this context, the business model was adjusted to fit the technological or market opportunity and enable the company to eventually capture value from it (Chesbrough \& Rosenbloom, n.d., p. 2; Casadesus-Masanell \& Zhu, 2013, p. 464). More recently, however, it became obvious that traditional types of innovation alone are not sufficient enough to obtain competitive advantage. Consequently, business model innovation itself became increasingly important and thus accepted as a distinct object of innovation (Stampfl, 2016, p. 37). The purpose of business model innovation does not lie in launching technological innovations, but rather in shifting from product-centered value creation to one that focuses on the associated business operations (Csik, 2014, pp. 32-33).

Based on this increasing interest, scientists have generated various definitions in order to describe the essence of business model innovation. However, these attempts have not yet resulted in one generally accepted definition (Csik, 2014, p. 34). Building on the definition of 
business models, Casadesus-Masanell and Zhu (2013, p. 464) summarize: "at root, business model innovation refers to the search of new logics of the firm and new ways to create and capture value for its stakeholders, and focuses primarily on finding new ways to generate revenues and define value propositions for customers, suppliers and partners". While most authors agree on business model innovation as a process of recombining the elements of the business model, the classification regarding the significance of each element varies (Mitchell \& Coles, 2004, p. 17; Osterwalder \& Pigneur, 2010, p. 136; Schallmo, 2013, p. 23).

Moore (2006, p. 88) and Comes and Berniker (2008, p. 78) consider the value proposition to be the significant element that needs to be changed. Moore (2006, p. 88) additionally focuses on the value chain, while Comes and Berniker (2008, p. 78) mark the revenue model as a lever for business model innovation. Osterwalder and Pigneur (2010, p. 136) pick up all four elements by stating that business model innovation is "[...] about creating new mechanisms to create value and derive revenues [...] [and] [...] about challenging orthodoxies to design original models that meet unsatisfied, new, or hidden customer needs". They further suppose that reinventing one of the four epicenters (resource-driven, offer-driven, customer driven, finance-driven) is sufficient to impact the remaining elements and thus innovate the business model as a whole (Osterwalder \& Pigneur, 2010, p. 138). While this methodology highlights the interdependency of the business model components (Hacklin \& Wallnöfer, 2012, p. 171), this dissertation, however, holds the predominant view of academic literature, in which authors specify that at least two business model elements need to be reinvented to deliver value in a new way (Csik, 2014, p. 35; Schallmo, 2013a, p. 27; Lindgardt et al., 2009, p. 2).

Besides concentrating on the elements of business models, Lindgardt et al. (2009, p. 2) state that business model innovation "can provide a way to break out of intense competition, under which product or process innovations are easily imitated [...]" and thus underline its ability to achieve competitive advantage, while at the same time prevent imitation form competitors. Mitchell and Coles (2004, p. 17) also highlight its ability to achieve sustainable competitive advantage by stating that "a business model replacement improves performance [...] versus the competition [...] [and creates] sustained enhancements in company earnings, cash flow and revenues", while also picking up the element of providing "product or service offerings to customers $[\ldots]$ that were not previously available". To execute business model innovation, Osterwalder and Pigneur (2010, p. 136) advise not to observe competitors, since "business model innovation is not about copying or benchmarking". Referring to the customer-perspective to indicate the degree of novelty, Skarzynski and Gibson (2008, p. 211) point out that "business model innovation is about creating fundamentally new kinds of businesses, or about bringing more strategic variety into the business you are already in - the kind of variety that is highly valued by customers".

Regarding these findings, it becomes obvious that existing definitions of business model innovation contain different elements and characteristics of the business model and innovation definition (Schallmo, 2013, p. 28). Figure 1 illustrates this combination of relevant aspects of these definitions. 


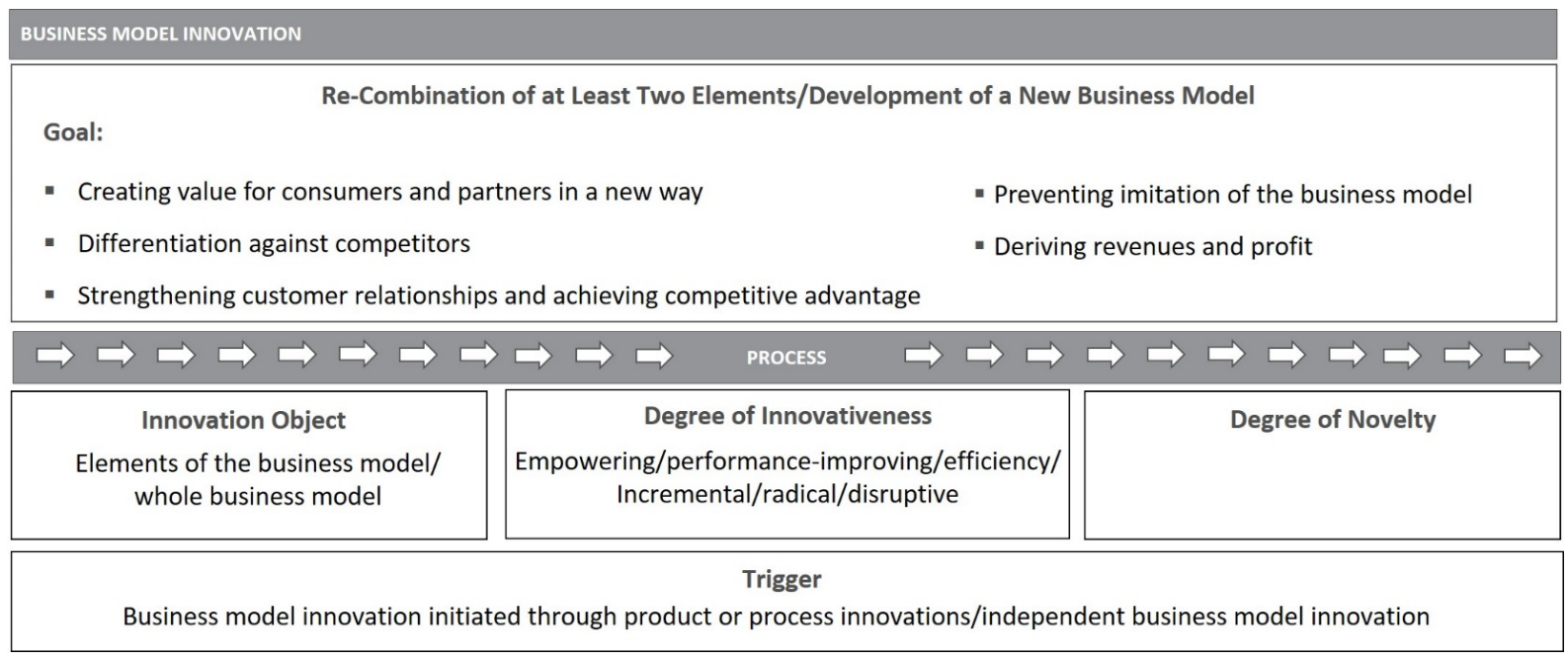

Figure 1. Elements of business model innovation (Schallmo, 2013, p. 29; Stampfl, 2016, p. 39)

For this paper, business model innovation describes a process that completely renews a business model or recombines at least two elements of it, in order to create and deliver a value proposition in a way that the customer considers new and innovative to a certain degree. Therefore, it strengthens the customer relationship, fosters differentiation from competitors, prevents imitation and hereby ultimately generates growth, revenues and profit (Mitchel\&Coles, 2003, p. 17; Schallmo, 2013, p. 29; Stampfl, 2016, p. 39). Figure 2 shows the four generally accepted steps of business model innovation (Schallmo, 2013, pp. 48-109).

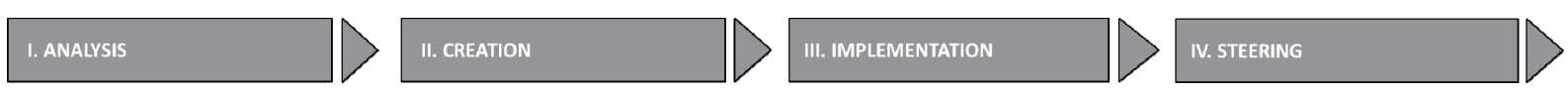

Figure 2. The four steps of business model innovation (Schallmo, 2013, p. 109)

\subsubsection{Organizational Mindset}

Organizational mindset is covered by the definition of the term dominant logic in detail. Dominant logic is the prevailing thinking and behavioral pattern of decision makers in an organization based on experience. It contains key assumptions about its identity and is the basis of important decision-making (Bettis\&Prahalad, 1986).

Dominant logic includes the following dimensions and elements:

- Level of Application: Dominant logic prevails in the entire organization (Bettis\&Prahalad, 1986).

- Underlying Theory: Dominant logic has its roots in cognitive psychology (Bettis, 2000).

- Elements: Dominant logic combines behavioral and cognitive elements (Bettis, 2000).

The objective of the dominant logic is to describe the dominant way how decision makers in organizations think and act (Bettis, Wong\&Blettner, 2011, p.351). 


\section{Macrothink}

\subsubsection{The Role of the Dominant Logic within an Organization}

According to Franke\&Zu Knyphausen-Aufsess (2014, p. 36), an organization's dominant logic is determined by the specification and configuration of internal and external antecedents. Internal antecedents refer to the organization itself, its members and elements. Franke\&Zu Knyphausen-Aufsess (2014, p. 36) assign them to an individual, top-management team and organizational level. External antecedents are predetermined by an organization's environment and are thus mostly immutable by the organization. Dominant logic evolves when the internal antecedents fit the organization's environment in a way that enables a company to obtain a successful performance. Figure 3 elaborates the antecedents, as well as the function and reinforcement of dominant logic.

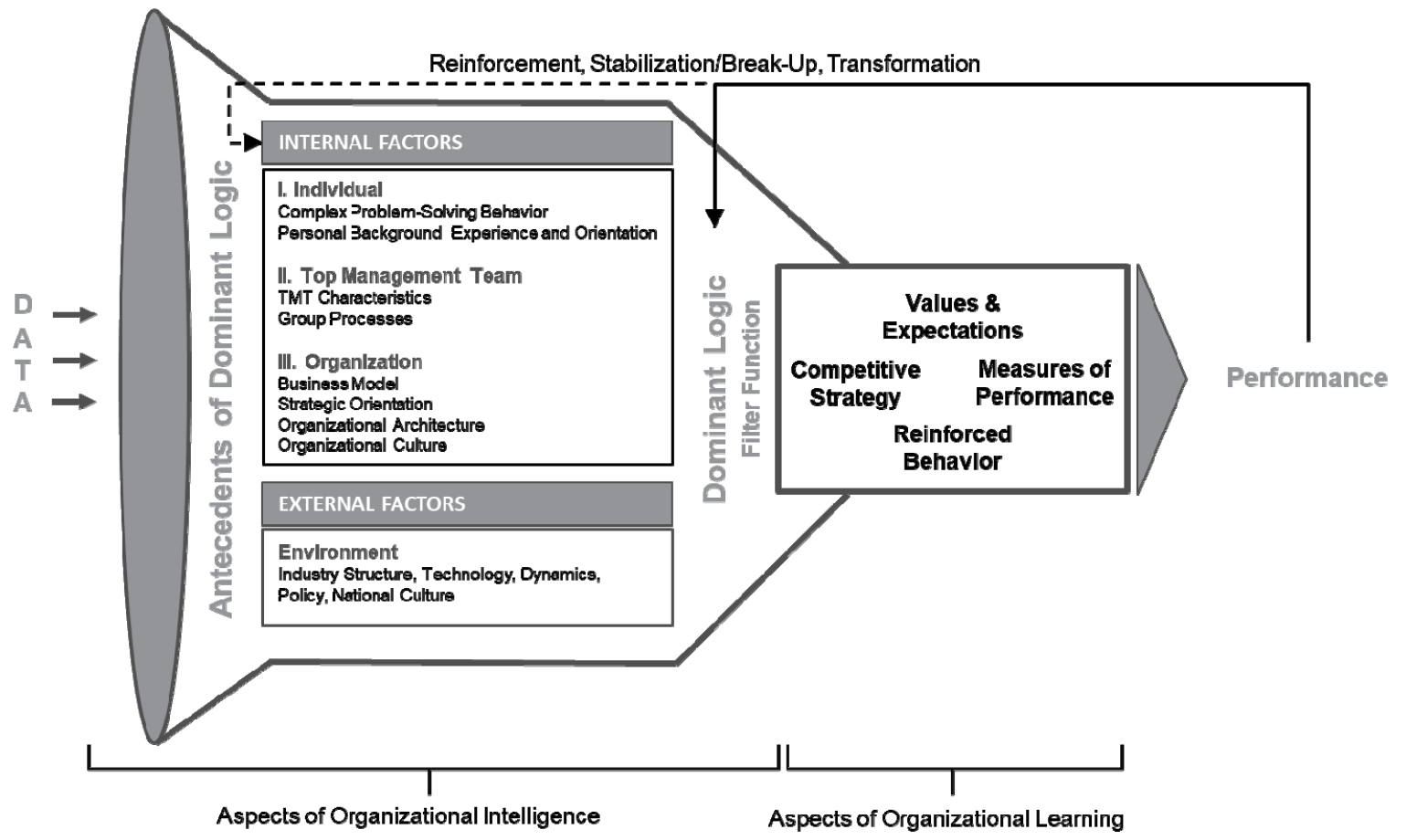

Figure 3. Antecedents and function of dominant logic (Franke\&Zu Knyphausen-Aufsess, 2014, p. 35; Bettis\&Prahalad, 1995, p. 7)

Figure 3 also illustrates the filter function of dominant logic. Based on the fit between internal and external antecedents, dominant logic filters relevant data and directs an organization's attention to it. The filtered data is then incorporated into a strategy, values, expectations, performance measures and reinforced behavior of an organization (Bettis\&Prahalad, 1995, p. 7). These determine an organization's performance. This illustrates that dominant logic presents an aspect of organizational intelligence, from which organizational learning can emerge. Organizational learning then again shapes the organizational intelligence through feedback loops. The dominant logic itself, as well as its internal antecedents are reinforced through a successful performance (Bettis\&Prahalad, 1995, p. 7). In managerial practice, this reinforces the consistency of decisions made in the organization (Csik, 2014, p. 38). Antecedents, such as established structures, procedures, systems, routines and processes, embody the dominant logic and direct the attention of managers to issues that are deemed 
important by it. Furthermore, dominant logic provides information, values and decision rules, which standardize and simplify the decision-making process for managers and employees throughout the organization (Bettis, Wong\&Blettner, 2011, pp. 372-373). Consequently, as long as there is no significant change in the environment (and thus no need to adapt the internal antecedents), dominant logic "can provide a highly effective and efficient means of managing the organization", reduce complexity, enhance consistency and thereby foster the overall stability of an organization (Bettis, Wong, \& Blettner, 2011, pp. 372-373).

In the long term though, dominant logic consistently increases the homogeneity of the organization and, at the same time, its inflexibility, inefficiency, inadaptability and inability to innovate (Wördenweber, Eggert, \& Schmitt, 2012, pp. 50-51, 60). Hence, when a significant change in the environment occurs, inflexible internal antecedents present a major obstacle. (Bettis, Wong, \& Blettner, 2011, p. 373; Csik, 2014, p. 38; Bouchikhi \& Kimberly, 2003). For example, the tools that managers use to make strategic decisions in congruence with the dominant logic are built on learnings and an environment of the past.

As the environment changes, they will no longer be applicable (Bettis, Wong, \& Blettner, 2011, p. 373; Bettis \& Prahalad, 2000, pp. 126-127, 130). This forces managers and employees to rethink and unlearn, which means adapting or eliminating elements of internal antecedents to make room for new mental maps (Bettis \& Prahalad, 2000, pp. 130-136). Especially in high-velocity environments an organization's ability to identify and react to external changes depends on the top-management's ability to continuously evaluate the fit between the organization's dominant logic and its environment, as well as their willingness to modify or completely unlearn it if necessary (Franke\&Zu Knyphausen-Aufsess, 2014, pp. 46, 52). This implies that if a change of the external antecedents destroys this fit, a reconfiguration of the internal antecedents is needed to achieve a new fit between an organization's set of choices and its environment (Franke\&Zu Knyphausen-Aufsess, 2014, p. 52).

\subsubsection{The Influence of Dominant Logic on Business Model Innovation}

As elaborated in the previous chapter, the dominant logic can particularly impede an organization's ability to innovate by filtering and restricting the management's perception, awareness and understanding of the inter- and intra-organizational context. Aspects not deemed important by the dominant logic are mostly ignored. Consequently, information that possibly indicate a change of the environment and therefore a need for the company to adapt and innovate itself may not reach the relevant decision-making processes (Csik, 2014, pp. 38-39; Tikkanen et al., 2005, p. 792; Hacklin \& Wallnöfer, 2012, p. 170).

Additionally to the elaborated definition, Tikkanen et al. (2005, p. 790) conceptualize a business model not only as a "sum of material, objectively existing in structures and processes" but also as "cognitive meaning structures at the level of a business organization". This highlights that the dominant logic of a company is not only strongly interlinked with the business model but even drives the tendency to avoid business model revision and thus 'protects' the existing business model (Bouchikhi \& Kimberly, 2003; Csik, 2014, p. 39; Cavalcante, Kesting, \& Ulhoi, 2011, p. 1328). Tikkanen et al. (2005, p. 791) specify that "in 


\section{Ml Macrothink}

practice, the cognitive aspects of the business model are firstly constituted by the meanings and meaning structures that actors maintain about the components of the business model. Second, the cognitive aspects also relate to the way in which actors perceive the functioning of the business model". This implicates that a strongly anchored dominant logic can constrain a company's strategic options to an extent that it is not able to cope with a changing environment (Bouchikhi \& Kimberly, 2003). Cavalcante, Kesting, and Ulhoi (2011, p. 1328) point out that "managers might fail to recognize, explore, seize and exploit valuable new technological and/or market opportunities, since they are not consistent with the present business model".

Regarding these statements, it can be implicated that a firm's dominant logic can significantly influence the business model innovation process. In particular, these findings imply that dominant logic impedes a comprehensive analysis of the company and its eco-system for potential levers of disruption, as well as an organization's ability to exploit them by creating new business model ideas. Tovstiga and Birchall (2014, pp. 1-2) confirm this assumption by stating that "managers of incumbent companies typically fail to recognize disruptions as opportunities because the potential new markets lie outside their existing resource base" and further that dominant logic prevents them from "recognizing the developing market for the threat that it really poses to them".

Hacklin and Wallnöfer (2012, p. 166) agree on these statements after conducting a single-case study in which business models were used as a tool for strategic decision-making. In particular, they explore the cognitive stages that a workshop group goes through during the steps of analysis and creation within the business model innovation process (Hacklin \& Wallnöfer, 2012, p. 178). Figure 4 visualizes these cognitive stages.

\begin{tabular}{|c|c|c|c|c|c|}
\hline \multicolumn{4}{|c|}{ ANALYSIS } & \multicolumn{2}{|c|}{ CREATION } \\
\hline $\begin{array}{l}\text { Abstraction } \\
\text { Skepticism }\end{array}$ & $\begin{array}{l}\text { Experimenting } \\
\text { With Language }\end{array}$ & $\begin{array}{l}\text { Consensus and } \\
\text { Personal } \\
\text { Identification }\end{array}$ & $\begin{array}{l}\text { Defending the } \\
\text { Current State }\end{array}$ & $\begin{array}{c}\text { Deliberate Team } \\
\text { Creativity }\end{array}$ & $\begin{array}{l}\text { Objective } \\
\text { Feasibility }\end{array}$ \\
\hline $\begin{array}{l}\text { Not believing in } \\
\text { the business } \\
\text { model concept, } \\
\text { seeing it as too } \\
\text { broed and } \\
\text { general }\end{array}$ & $\begin{array}{l}\text { Building } \\
\text { analogies } \\
\text { between the } \\
\text { organization's } \\
\text { way of describing } \\
\text { the business } \\
\text { model and the } \\
\text { terminology of } \\
\text { the business } \\
\text { model concept }\end{array}$ & $\begin{array}{l}\text { Collective } \\
\text { understanding, } \\
\text { ownership and } \\
\text { identification of } \\
\text { current business } \\
\text { model }\end{array}$ & $\begin{array}{l}\text { Intrinsic } \\
\text { resistance } \\
\text { against altering } \\
\text { the existing } \\
\text { business model }\end{array}$ & $\begin{array}{l}\text { Creative and out- } \\
\text { of-the-box } \\
\text { scenario building } \\
\text { without } \\
\text { considering the } \\
\text { existing model } \\
\text { "this is now how it } \\
\text { should look like" }\end{array}$ & $\begin{array}{l}\text { Analyzing ideas } \\
\text { regarding current } \\
\text { capabilities and } \\
\text { assets }\end{array}$ \\
\hline
\end{tabular}

Figure 4. Interactive Stages of Analyzing and Creating Business Models (Hacklin \& Wallnöfer, 2012, p. 178)

Their findings emphasize the obstacles that occur due to dominant logic within the steps of analysis and creation. The observation that personal identification with the current business model rises the intrinsic resistance of altering single elements of it, is strongly linked to the existence of dominant logic. Furthermore, it bears "the risk for strategy practitioners to ignore changes in their environment" Hacklin and Wallnöfer (2012, p. 166). To reset the "mental models on which perceptual filters are based", Hacklin and Wallnöfer (2012, p. 166) suggest 
several measures to induce an unlearning of the established logics. They further outline the importance of using systematic creativity tools to overcome the intrinsic resistance and create substantial ideas for new business models.

\subsubsection{A New Methodology for Business Model Innovation}

According Lang (2020, pp. 435-449) the role of organizational mindset is scarcely addressed. Instead, authors focus on an abstract sequence of steps without considering the impact of the cognitive, behavioral, structural and cultural elements of an organization that form the dominant logic. All findings consider, it becomes obvious that existing academic methodologies on business model innovation do not cover the critical factor of dominant logic within their recommended process. Consequently, as the generation of potentially disruptive business models is significantly determined by overcoming the blinders of dominant logic to successfully identify and exploit changes of the environment, an established organization cannot rely on these existing methodologies. Rather, a methodology that is specifically designed to address the dominant logic as a barrier against innovation within the first steps of the business model innovation process, is needed. Emphasizing the current research gap, this conclusion justifies the research objective of developing a methodology that enables established companies to generate a business model innovation by acknowledging and addressing the firm's dominant logic as the main barrier within the business model innovation process.

After identifying that the steps Analysis and Creation are mostly affected by the influence of dominant logic, the following chapter aims at developing the according strategy which acknowledges and effectively addresses this innovation barrier within these steps.

\subsubsection{Strategy Overview}

At first glance, it seems to be the obvious choice to follow the methodologies of Lindgardt et al. (2009, pp. 6-7) and Osterwalder and Pigneur (2010, pp. 249-251), by simply prepending an extended phase of mobilization to overcome the dominant logic within the business model phases of analysis and creation. However, organizational changes take place within a living system and present a complex process consisting of merging and intertwining phases. Thus, it is difficult to assure an effective overcoming of dominant logic by only dedicating one segregated methodology phase to it (Kotter, 2012, pp. 25-27). Therefore, including an additional, prepending step to an otherwise unmodified business model innovation process, does not seem as expedient as initially assumed. Consequently, the demand for a holistic strategy, which cohesively aligns the business model innovation process along the cognitive process of abandoning the dominant logic, becomes obvious. Scientific literature however does not provide a strategic methodology, which incorporates and parallelly addresses both processes in a sufficient way. To close this research gap, the article illustrates a theoretical methodology by systematically aligning an overarching process of organizational change to a particularly arranged business model innovation process. Therefore, a strategic methodology, which provides a pathway for overcoming the dominant logic and thereby enables the generation of a business model innovation with disruptive potential, is created. 


\section{Macrothink}

By applying Scharmer's (2016, p. 141) Theory U, this methodology builds on "a road map for crossing the threshold to authentic change and renewal", to overcome the barriers of dominant logic during business model innovation. As it has proven to be successful with regard to inducing innovation and change within corporate organizations, it constitutes the overarching process of organizational change within this methodology (Scharmer, pp. 14-18). In particular, Scharmer's (2016, pp. 28, 39, 40-41, 161, 163-164, 167) method facilitates the transition from a reconfirming and rule-reenacting habit of paying attention to a new mindset that enables an organization to recognize itself as part of a collective ecosystem and operate with a sense of emerging future possibilities. As Scharmer's $(2016$, pp. 6, 12) methodology is designed in the shape of the letter $U$, he describes the main phases of change and renewal as "moving down the left side of the U" and "moving up the right side of the U" (Scharmer, 2016, p. 11).

After moving down the left side of the U which describes "opening up and dealing with the resistance of thought, emotion and will", the individual or organization faces a threshold, at the bottom of the $\mathrm{U}$, which requires letting go of the dominant logic and letting come a new, open mindset $(2016$, pp. 7, 11). This new mindset enables the identification of disruptive opportunities and the creation of appropriate business model ideas, when moving up the right side of the U (Scharmer, 2016, p. 11).

By aligning this methodology along the business model phases of analysis and creation, a methodology for generating a business model innovation with disruptive potential, is created. The methodology is specifically designed to lead the pathway for the designated core group of the innovation initiative. Considering the open innovation methodology, this core group consists of internal and external stakeholders. To facilitate co-creation further, certain steps of the methodology are designed to take place in a workshop setting. The methodology is depicted in Figure 5.

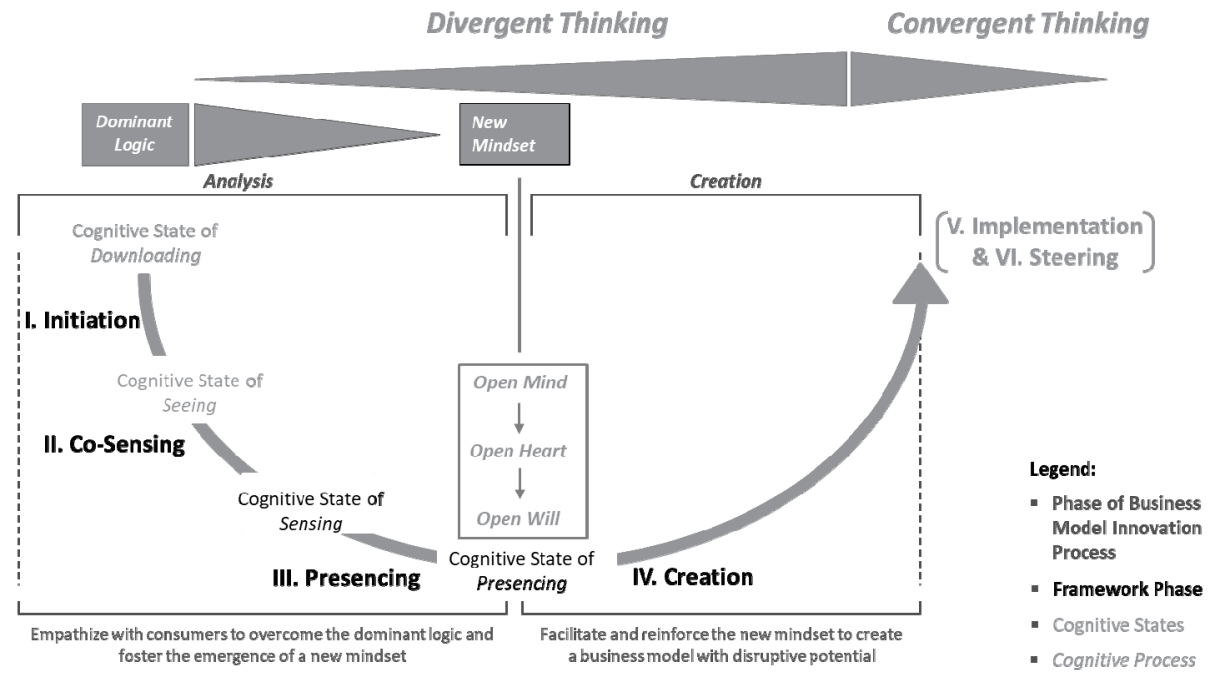

Figure 5. Role of Dominant Logic in the Steps of Business Model Innovation based on Scharmer (n.d., pp. 6, 12) 
As illustrated above, the blinding effect of dominant logic decreases during the first three phases of the methodology, which simultaneously facilitates the occurrence of divergent thinking. This allows the core group to generate insights, produce various valuable ideas and explore different options. Before implementing a business model idea, convergent thinking enables optimizing and finalizing individual business model elements and evaluating the business model as a whole regarding its disruptive potential (Rogers, 2016, pp. 132-133, $147,152)$. With regard to Lewin's $(2009$, p. 76) emphasis on the importance of permanency to successfully anchor organizational change, this methodology does not only aim at overcoming the dominant logic within the first three methodology phases, but also avoids relapsing into old thinking patterns during the phase of creation. Thus it amplifies the disruptive potential of generated business model innovations (Csik, 2014, pp. 51,53).

In the following, the distinct phases and steps within the methodology are elaborated in detail.

Phase I - Initiation: Corresponding to Scharmer (2016, p. 6), moving down the left side of the U starts with the phase of initiation. This phase aims at changing the core group's way of paying attention from downloading, meaning the habitual thinking reinforced by the dominant logic, to seeing, meaning the ability to access objective, rational intelligence on individual and group level. Scharmer (2016, pp. 37-38, 40-41; n.d., p. 12) describes this open mind as the first element of the new mindset. The open mind is achieved by implementing three distinctive steps: set the preconditions, clarify intent, create urgency and move into context. Setting the preconditions aims at creating the appropriate physical (e.g. office), relational (assembling the right team for the core group) and time space for the innovation initiative. By clarifying the intent of the innovation initiative, the core group's activities are directed and aligned along the business model innovation process. Furthermore, to increase intrinsic motivation, this step includes creating a sense of urgency for change among the core group. To complete the initiation, the core group has to move into context.

By doing so, the core group enters the business model phase of analysis. Moving into context, aims at providing holistic insights on the company's overall eco-system. As the key for disruptive innovation "lies in the need of the customers" (Hopp et. al, 2018, pp. 4-5), the customer segment presents the first business model element to be considered.

This methodology follows the initial methodology of Christensen et al. (1997, pp. 11-12) of disrupting the market by targeting consumers, who are unserved by incumbents' offerings until now (outside-in customer trajectory) (Rogers, 2016, p. 214). To investigate levers for disruption further, analyzing the surrounding eco-system, as well as the existing resources within the company, is integrated into moving into context. Methods for moving into context include shadowing current non-customers, deep-listening interviews with non-customers and compiling the resource map and the eco-system map.

Phase II - Co-Sensing: To detect potential levers for disruption within the environment, the core group needs to proceed with unlearning the dominant logic within the phase of co-sensing. This phase aims at achieving an open heart among the core group, which describes the ability to access emotional intelligence and redirect perspectives on individual 
and group level. The open heart presents the second element of the new mindset (Scharmer, 2016, pp. 37, 40-41; Scharmer, n.d., p. 12). As recommended by Christensen et al. (1997, p. $12 ; 2015,2016)$, this methodology follows a human-focused, consumer-centric methodology to generate a business model innovation that aims at disruption. Therefore, the focus within co-sensing lies in enabling the core group to sense the experiences, thoughts, motivations and frustrations of consumers. To facilitate the sensing, this phase is meant to take place within a workshop setting. Participants consist of the core group and the respective consumers investigated during moving into context. Within this feedback session, workshop participants are able to discuss, concretize and visualize consumers' values, beliefs, objectives, motivations, struggles and experiences. In doing so, the core group empathizes with consumers and understands why they are essentially not purchasing and using the current offerings.

Phase III - Presencing: To complete the cultivation of a new mindset, moving down the left side of the $U$ is concluded by crossing the threshold of renewal and change at the bottom of the $U$ during presencing (Scharmer, n.d., pp. 7, 11). The aim of this phase is to create an open will, meaning the ability to fully unlearn and access the authentic purpose of the individual and the group (Scharmer, 2016, pp. 37, 40-41; Scharmer, n.d., p. 12). Hence, presencing completes overcoming the dominant logic within the business model innovation process and facilitates the emergence of a new mindset, which consists of an open mind, open heart and open will (Scharmer, 2016, p. 176). Creating an opportunity map enables the workshop participants to connect insights, recognize disruptive opportunities within the environment and, thus, induces a collective will for change (Scharmer, 2016, pp. 41, 163, 165; Sniukas, Lee, \& Morasky, 2016, p. 73). Compiling the opportunity map and completing the cognitive process of presencing defines the end of the first workshop setting.

Phase IV - Creation: Moving up the right side of the U describes utilizing the newly cultivated mindset to operate outside of the dominant logic and create valuable ideas for potentially disruptive business models (Scharmer, 2016, p. 38). To do so, the identified opportunities need to be crystallized in order to manifest a clear vision of the company's disruptive identity within the future eco-system (Scharmer, 2016, pp. 39, 188, 191, 199). To gain this clear vision, the methodology recommends specifying the identified opportunities, regarding the jobs that consumers seek to be done within them. This presents the starting point for developing a value proposition (Christensen et al., 2016; Rogers, 2016, p. 204). The non-customer profile template enables the core group to visualize the previously gathered information in a way that reveals which jobs current non-customers seek to be done (Osterwalder et al., 2014, pp. 12-16). To exploit these crystallized opportunities by getting the job done, ideas for business models are generated during creation. To effectively utilize the new mindset during idea generating, the methodology delivers a composition of intuitive and systematic creativity techniques to stimulate the core groups' creative thinking within an idea-generating workshop (Gassmann, Frankenberger and Csik, pp. 2-3). Through their application, the core group is able to create holistic business model ideas, consisting of a value proposition, revenue model and value chain, for targeting a certain customer segment. Visual thinking tools, such as the value proposition canvas, further facilitate the creative 
thinking among the core group (Osterwalder et al., 2014, pp. 12-16, 42-43, 61). To avoid market failure at the best possible rate, this methodology implements the iterative design-thinking element of prototyping into the creation phase. Contrary to traditional innovation processes, in which decision-making is based on internal knowledge and expertise, prototyping aims at integrating credible consumer feedback, as early as possible, into the development process (Rogers, 2016, pp. 124, 127, 132, 138). By letting consumers interact with a prototype of the business model or certain elements of it, the underlying assumptions on which the business model idea is based, can be tested (Rogers, 2016, p. 140; Liedtka\&Ogilvie, 2011, pp. 131-132). By applying prototyping in an iterative manner, consumer data is gained and refined in order to reduce the amount of assumptions and consequently increase the amount of knowledge (Tendayi, Toma and Gons, 2017, p. 143). Thereby, the core group is able to adjust the generated business model in a way that increases its chance of consumer adoption and, thus it's potential to disrupt the industry (Gerstbach, 2017, p. 241; Scharmer, 2016, p. 209; Vianna et al., 2014, p. 126). After obtaining a promising business model through sufficient iteration, the methodology suggests finishing the creation phase by evaluating the business model's disruptive potential. When passing the evaluation, the business model is considered to have reasonable disruptive potential and, hence, considered qualified for implementation.

Recommendations for implementing the generated business model into existing corporate structures and launching it to the market with the Phases Implementation and Steering are not included in the present methodology. Considering the research objective and that the theoretical research identified the business model phases Analysis and Creation to be most affected by the dominant logic, the subsequent phases are neglected.

\subsection{Research Strategy}

For validating and refining the preliminary results of the business model innovation methodology is applied and tested in focus group workshops. The workshops are executed in total nine time and three times per business sector with teams of the following industries:

- Automotive: Workshop with an automotive supplier for bearings, transmissions and clutches who is challenged by developing digital competencies for their business field.

- Home Appliances: Workshop with a home appliance producer who is executing a dual transformation methodology of products and digital services.

- High-Tech: Workshop with a consulting company in the high-tech business sector. The company's business model is in a transition from project to an overall partner business.

\subsubsection{Overview of Structure for Focus Group Workshops $(\mathrm{n}=9)$}

Figure 6 outlines the structure for the focus group workshops. The structure covers the workshop agenda with its four steps based with goals, applied methods and tools for each step.

In order to provide clarity and structure, the applied workshop methods are consolidated into 


\section{Macrothink}

Journal of Entrepreneurship and Business Innovation

ISSN 2332-8851 2020, Vol. 7, No. 2

the phases Initiation, Co-Sensing, Presencing and Creation as described below. The selected methods and duration are based on a first estimation and serve as a guideline for each focus group workshop.

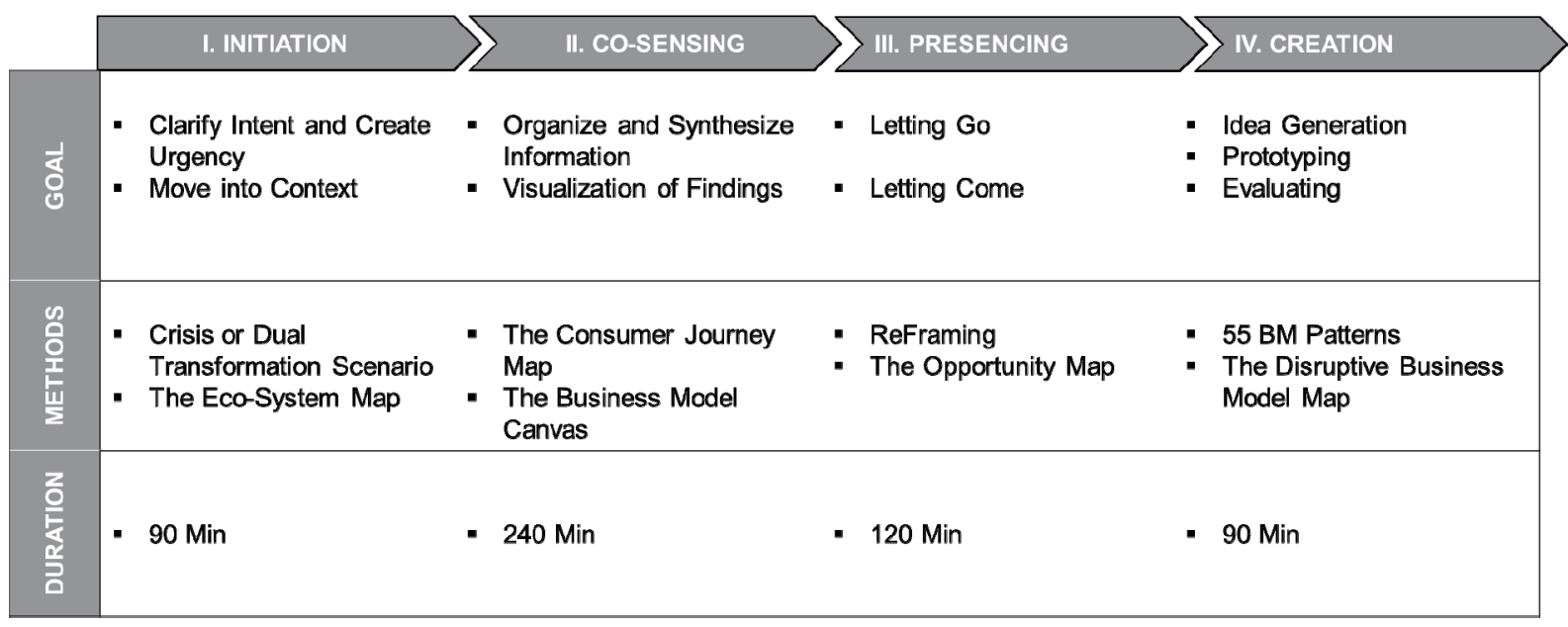

Figure 6. Research Strategy for Focus Group Workshop

Phase I - Initiation: In the first phase, a Crisis (Note 1) or Dual Transformation (Note 2) Scenario is presented in an introduction to the focus group. The main goal is to develop and provoking this clear intent on the overall workshop goals. In a second step, the eco-system of the respective company is outlined in order to understand the relations and transactions with all relevant market players using the Eco-System Map.

Phase II - Co-Sensing: This phase starts with the development of a Consumer Journey Map (Figure 7) of a typical customer followed by the realization of the Lean Business Model Canvas (Figure 8). The creation of the business model canvas illustrates the set of activities which are currently undertaken to create value for the customers, ecosystem and the company itself.

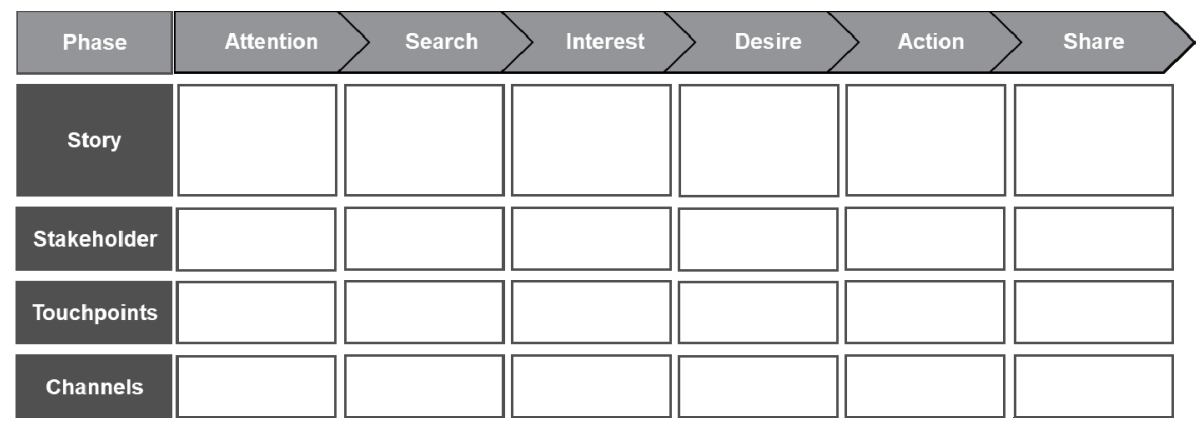

Figure 7: The Consumer Journey Map (Kreutzer, 2018)x 


\begin{tabular}{|c|c|c|c|c|}
\hline \multirow[t]{2}{*}{$\begin{array}{l}\text { Jobs-to- } \\
\text { be-done } \\
\text { The most relevant job- } \\
\text { statements }\end{array}$} & $\begin{array}{l}\text { Solution } \\
\text { How the business model } \\
\text { solves the Jobs-to-be- } \\
\text { done }\end{array}$ & \multirow[t]{2}{*}{$\begin{array}{l}\text { Value Proposition } \\
\text { Whythis busincss model } \\
\text { Is different and worth } \\
\text { getting attention }\end{array}$} & $\begin{array}{l}\text { Unfair Advantage } \\
\text { Compettlve advantage } \\
\text { that prevents imitation }\end{array}$ & \multirow[t]{2}{*}{$\begin{array}{l}\text { Noncustomer } \\
\text { Segment } \\
\text { Targeted } \\
\text { consumer } \\
\text { segment }\end{array}$} \\
\hline & $\begin{array}{l}\text { Key Metrics } \\
\text { Key numbers that } \\
\text { measure real-time } \\
\text { success regardlng } \\
\text { acquisition, activation, } \\
\text { retention, revenue and } \\
\text { referral }\end{array}$ & & $\begin{array}{l}\text { Channels } \\
\text { Significant path to } \\
\text { approach consumers }\end{array}$ & \\
\hline \multicolumn{2}{|c|}{ 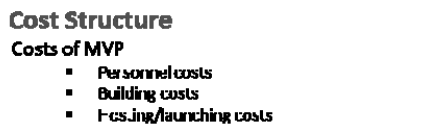 } & \multicolumn{3}{|c|}{$\begin{array}{l}\text { Revenue Streams } \\
\text { Pricing of the MVP } \\
\text { : Prioe is part of the product } \\
\text { - Prioe co Telates vith nonaustomer segment } \\
\text { - Getting paid is firs: form cf validation }\end{array}$} \\
\hline
\end{tabular}

Figure 8: Lean Business Model Canvas (Maurya, 2012)

Phase III - Presencing: The results of the first two phases cover the value network by the eco-system map and the value proposition, which is part of the business model canvas. The presencing phase, which represent the most important element of the workshops, focuses on the disruption of these two elements by using the ReFraming (Note 3) and Opportunity Map (Figure 9). In the first step of the phase, the workshop participants are asked to formulate statements on sticky notes about the ecosystem and the business model canvas by applying the reframing method. The statements describe, how the company currently creates value. As guidance, participants are advised to formulate the statements according to each arrow in the ecosystem and each component in the business model canvas. The workshop participants could either write sentences in positive or negative formulation. For example: "The company currently sells spare-parts only via several middleman." The main goal is to uncover the dominant mindset of the organization by creating positive or negative value statements.

Afterwards, the workshop participants are divided in two small groups. Each group should pick three exemplary statements from above, of which they thought they are crucial for the current way of doing business. The team members with the highest expertise are questioned five times about the main reason of a selected statement. The ones with the fewest company insights posed the questions and the third team member wrote down the given answers.

For this exercise, the teams are given a limited amount of time of five minutes in which they should pose the why question as often as possible. The given time aims at causing instinctive answers. After the five minutes of asking and answering, the last given answer is written down on a sticky note. 


\section{Macrothink}
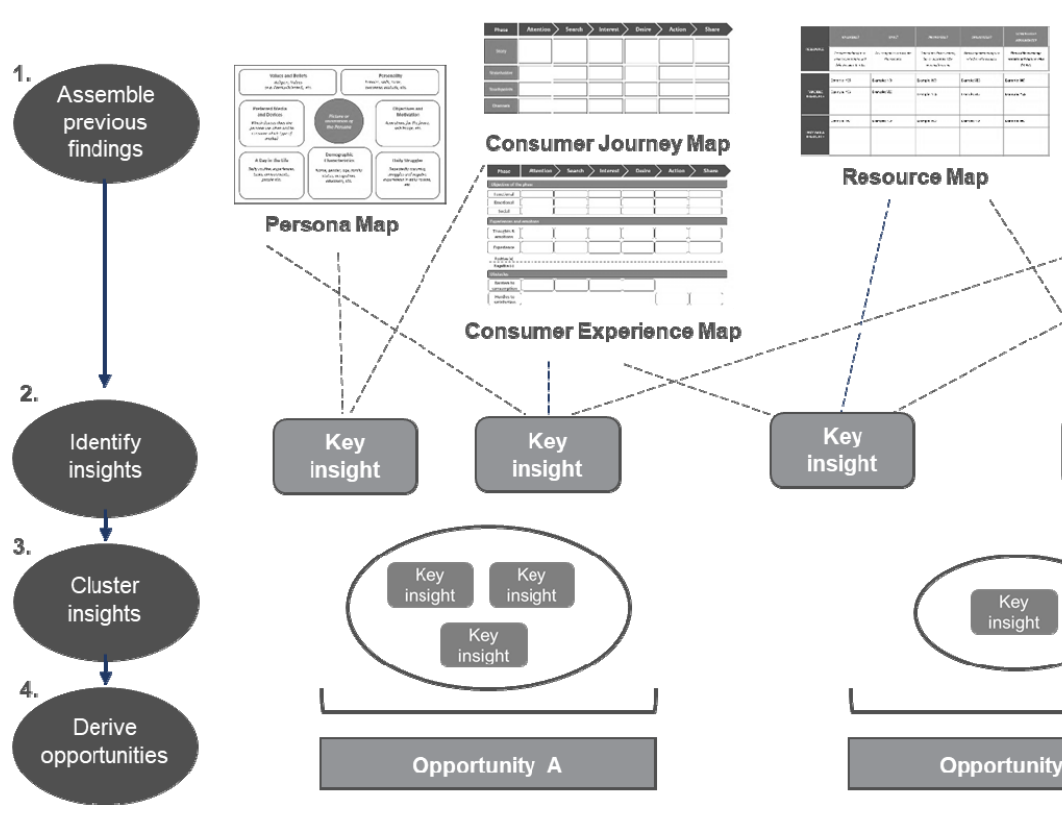

Consumer Experience Map
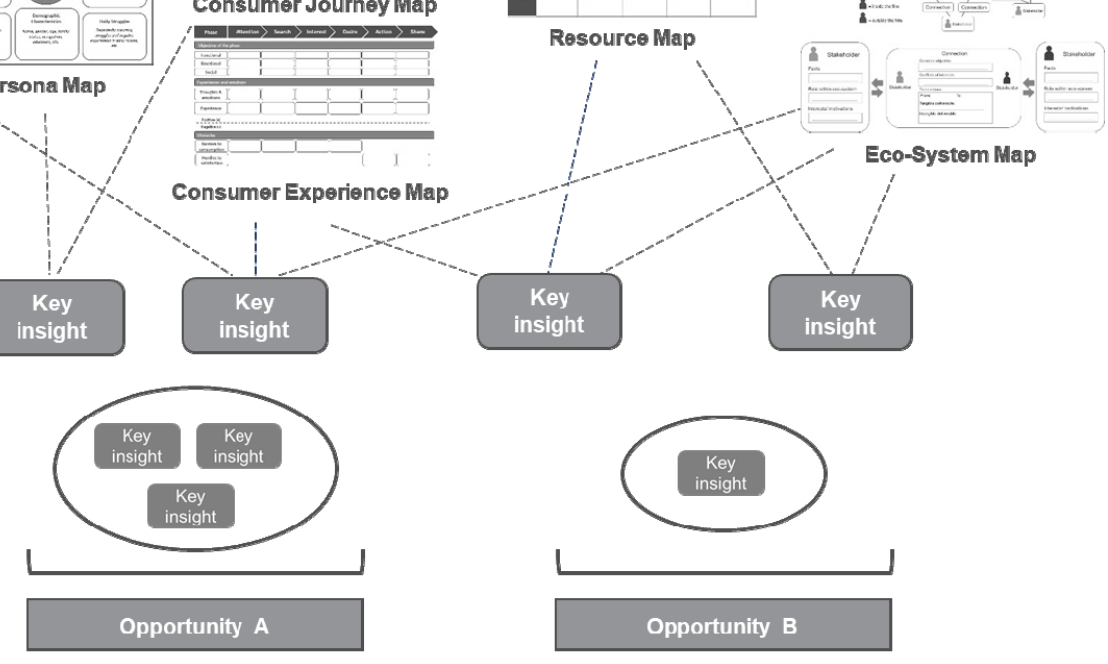

Figure 9. The Opportunity Map (Sniukas, Lee\&Morasky, 2016, p. 73)

Phase IV - Creation: Finally, in the last phase each group votes whether in a hypothetic future, any of these statements could be true. As most of new business models recombine existing ideas and concepts, it seems reasonable to use existing business models as inspirations and stimulate the idea by applying Business Model Pattern Cards (Gassmann, Frankenberger and Csik, n.d., p. 3). Deriving from their studies, Gassmann, Frankenberger and Csik (n.d., pp. 3-12) provide a card deck of 55 business model patterns, to stimulate creative thinking. Based on the results in combination with the inspirations of the Business Model Pattern Cards new disruptive eco-systems or business models are created. The groups directly set up the new disruptive business model canvas with the hypothesis about each of the components.

\section{Results}

\subsection{Focus Group Workshops Processed ( $n=9)$}

The critical evaluation of the results focus on the selected tools and methods of the business model innovation methodology. It also reflects on the workshop setup itself.

Time consuming: The tools and methods applied in the workshops revealed several findings. Illustrating the status quo with the help of the ecosystem and the business model canvas is necessary, in order to have a reference point. However, it turns out to be very time consuming. Through this, the status quo illustration appeared to be highly relevant, which, besides the fact, that it enables comparability to the incumbent, it is not for the actual generation of a new disruptive business model. People from outside the industry do not know the predominating industry beliefs and thereby break them automatically, whereas for incumbents the process is a lot more dragging, as they need to actively unlearn the dominant logic. 


\section{Macrothink}

Loss of motivation: Workshop participants partially lost dynamic and motivation by illustrating the current ecosystem and business model. Yet it is not possible, to dispense or shorten the illustration of the status quo. Instead workshop participants would have needed to be inspired and remotivated afterwards. Therefore, it is recommended for the future, to bring up impressive disruption examples like the first iPhone in the mobile phone and music player business, ITunes and Spotify, who revolutionized the music industry, Netflix, which replaced Blockbuster and Tesla and Google-Car, who are revolving the automotive industry (Matzler, 2016). Instead or additional trends with disruptive impact can be presented at this point of the workshops. Regardless to the loss in motivation, the illustration of the industry and business model with the help of the ecosystem and business model canvas succeeds and gives participants the understanding of the relevant levers for disruption.

Formulating the statements: The formulation the statements based on the illustrations is easy for the participants. They deliver countless opportunities for the 5 Why questioning and due to their multiplicity only a few are selected. It is quite challenging, for the workshop participants with which statements they would continue working in the next steps. The workshop members point out that all statements have a potential for disruption. In the workshops the participants are advised, to pick the ones, they seem most strange to them, as these may embody the biggest break with the dominant logic. However other parameters for the choice are possible as well.

Workshop participants pointed out, how powerful the 5 Why questioning technique is for them to identify the core of industry assumptions. However, they mention that not necessarily the last answer is the one which gets it to the point best. Instead the teams prefer picking any of the given answers, which they think, is most appropriate. Moreover, they point out that the time pressure is not leading to more instinctive answers. Instead, they prefer to limit the exercise to the number of posed Whys instead of time. For the future, the 5 Why questioning technique should therefore be used in its original form.

Workshop participants state that writing down statements on paper itself is a powerful tool, to illustrate industry assumptions which otherwise are subconsciously taken for granted. Writing down the followed reframed statements is also rated positively, as it gives participants "the allowance" to think in such an unconventional direction. Having the turnaround down on paper makes it more accessible. It proves that thereby the dominant logic, which would actually restrict these "strange" assumptions, could be outwitted. Reframing is mentioned to be the most powerful method from the workshop series.

Development of disruptive business models: In the following, the groups could think of new disruptive business model opportunities, for which their turnaround is true. Workshop participants give the feedback that they are interested in developing a disruptive business model idea based on the turnaround of the other group instead of their own, since this would be even more creative.

Although the small groups find a large number of ideas as starting points for disruptive business models, the whole group could finally not come down to a business model idea. It could not be evaluated from only one workshop what the reasons are that even though there 
are several ideas, the group could not conclude one disruptive idea in a new business model canvas. One hurdle in this final step is the focus on "having to be disruptive". Workshop participants are insecure, whether their ideas is disruptive enough. The definition on disruptive business models from the beginning appears to be insufficient. It is helpful to encourage disruptive thinking by giving concrete disruptive examples in the beginning. Pictures can stimulate people more than any theoretical words in that matter. However, disruption still seems somewhat too abstract for concluding ideas in a business model canvas.

Organizational mindset: Another reason, why workshop participants finally do not elaborate their ideas in a business model canvas seems to be the organizational mindset itself. It may hinders workshop participants to finally outline a business model, as they subconsciously already dismiss the idea because they rate it as being not implementable. It could not be assessed, whether the dominant logic is limiting to the creativity of disruptive ideas, since there is no industry foreign control group. All in all, the time proves to be insufficient, for the generation of a first draft of a disruptive business model. For the future, a series of workshops should be hosted for a workshop team. This also enables an iterative working style.

\subsection{Summary}

Concluding, the methods of the business model innovation methodology are successful in identifying relevant levers for disruption. Even several starting points for new disruptive business models are found. However the groups could not come down to final business model canvas. For the future, a rating system for the existing ideas and which one to work out in a first business model canvas draft should be integrated. Only discussing the ideas leads to no results. Moreover, for the future, it may be helpful to integrate a design thinking workshop at this point to get a clearer picture of the potential customer segment to address.

\section{Discussion}

The systematic theory analyzed the developed business model innovation methodology. This research extends previously published papers by Lindgartd et al. (2009, p. 2), Osterwalder\&Pigneur (2010, p. 250), Weiner et al. (2010, p. 54), Wirtz (2010, p. 193), Randles\&Lasch (2016, pp. 53-73) and Bocken et al. (2019, pp. 1498-1512). They acknowledge organizational mindset as an innovation barrier however do not give concrete advice how to overcome it. Moreover, Osterwalder\&Pigneur (2010, p. 250) are the only researchers who address it by implementing a step of mobilization into their process (Lang, 2020 , p. 445). Nevertheless, the recommended mobilization is not considered sufficient to fully overcome the barriers of organizational mindset, since it is not explicitly addressed. Lindgardt et al. (2009, pp. 6-7) also aim at mobilizing the organization by providing a set of concrete questions. This set serves as a tool to assess the company's current business model and its environment to raise awareness on strengths, weaknesses and potential threats and opportunities. They do not include a method to mobilize an organization's established mindset (Lang, 2020, p. 446).

Focusing on the practiced workshops for theory validation, it is not only the tools and 
methods which determine whether a workshop is successful or not. The conducted workshops reveal that several other parameters are crucial. Firstly, it is crucial that the team members are diverse, in order to have various and creative input through different mindsets. Diversity enables creative innovation. Any workshop can be only as good as the openness and willingness of its participants. The selected teams turn out to be very interested in the topic. In contrast to that, inner resistance of participants needs adequate change management, before an innovation workshop can be hosted at all.

Secondly, workshop hosts should encourage the workshop participants, who have not been with the companies for long, to pose putative non-adequate questions and point out, how valuable their non-knowledge is, in order to identify the dominant logic. The workshops reveal that person who are still new in the business have the tendency to fit in according to the dominant logic, rather than questioning. The workshop host should moreover help leaving the dominant logic, by making clear that the idea generation happens in a space of non-evaluation, non-judgment and converge. To support this, all ideas, no matter how unwise or irrelevant they seem should be written down on paper. Finally, workshop participants also express that it is important not to dispose ideas or statements too early.

In general, the company culture is deeply anchored in the thinking of people. As a result, the workshop participants follow the learned company's rules they are triggered on. One example for this is that one workshop participant feedbacks that considering companies core capabilities as a starting point to generate disruptive business model make innovation more realistic. This reveals how deeply embedded the inside-out perspective is, which the company's culture still follows. One workshop is not capable of implementing an innovative company culture and disruptive mindsets. An innovation friendly company culture is something that has to be promoted and encouraged through all management levels in daily business.

The workshops also reveal that an existing business model as a starting point, makes it really difficult to think of disruption. Looking back at the definition, disruption is an effect that describes the destruction of an existing business model. The concept of disruption therefore rather serves as an explanation why companies fail. Companies can try to disrupt their value chains, the other most crucial part for disruption to happen is that users or customers prefer the value proposition to the old. Even though tools and methods can help to find novel new value propositions, their disruptive effect cannot be intended.

\section{Conclusion}

In the following, the findings of the focus group workshops are utilized to assess the generated methodology and implicate appropriate refinements to increase its suitability for generating business model innovations with disruptive potential. In general, focus group participants agree with the overall methodology and composition of the methodology. Nevertheless, regarding the distinct phases and steps, specific remarks and recommendations, based on experiences, are given, to increase the methodology's appropriateness. Subsequently, the assessment of the methodology is outlined and refinements are elucidated. 


\section{MInstitute ${ }^{\text {Mink }}$}

The participants' feedback during the focus group workshops implicate that aligning the process of overcoming the organizational mindset with the business model innovation process, is more effective than implementing a prepending phase to it, in order to address the dominant logic. Consequently, the methodology's overarching methodology of aligning the business model innovation process to Scharmer's (2016, pp. 113-226) Theory U to overcome the dominant logic, create a new mindset and, thus, enable the identification and exploitation of disruptive opportunities, is considered sufficient. The strategic phase of initiation also correlates with the participants' recommendation on how to induce organizational change. On the one hand, creating a crisis scenario presents an effective methodology to uncover the depletion of the firm's competitive advantage and enable members of the organization to realize the necessity for innovating the business model. On the other hand, a clear intention and reinforcement from top-management facilitates the willingness to participate in and support the change, especially within established, medium-sized companies. Furthermore, excluding the physical space of the innovation initiative from the core business, is regarded as an effective means to support the unlearning of dominant logic. Operating from this outside space, conveys a sense of freedom to participants. This allows them to develop and pursuit ideas, without getting stifled by advocates of the current business model and embedded organizational structures. This affirms the methodology of the methodology, which implies that a physical space, in which not only the workshop phases but the overall operation of the innovation initiative can take place, is needed. With regard to the step moving into context during the initiation phase, participants underline that, especially with regard to established companies, the consideration of the existing value chain and the existing resources, as well as their level of flexibility, present valuable starting points. The methodology takes up on this methodology by integrating tools, such as the resource map or the eco-system map. However, following the participants' recommendation, an even more comprehensive analysis of the existing resources, be it in technology, knowledge, assets, structures or overall unused capacity, might transpire expedient. Additionally, according to the participants, the methodology needs to be extended to researching general trends during moving into context.

Integrating consumers into the phases of initiation, co-sensing and presencing, as part of an open innovation methodology, encourages and facilitates the process of moving down the left side of the $U$ and generating an open mind, open heart and open will. As participants note that consumers often lack the ability to identify and articulate their needs, integrating shadowing as the first step of qualitative consumer research, is considered effective to acknowledge and address this challenge. Refining the gathered insights via interviews and group discussions afterwards, provides the core group with clearer insights on the consumers' preferences, experiences, beliefs, actions, needs and wishes. The implementation of visualization tools within these steps, delivers tangible results to the core group and, thus, evokes a positive attitude and an open will towards the changes within the business model.

Moving down the left side of the $U$ and cultivating a new mindset, consisting of an open mind, open heart and open will, enables a clear definition of the disruptive opportunities within the eco-system. Taking the experts' remarks into account, several opportunity maps, 


\section{Ml Macrothink}

Journal of Entrepreneurship and Business Innovation

ISSN 2332-8851

2020, Vol. 7, No. 2

based on different scenario cases, should be created during presencing. Transferring these opportunities into clear job statements that aim to be solved within the phase of creation, paves the way for purposive idea generating and prototyping. The step of crystallizing, therefore, aligns with the experts' remarks on the importance of providing a clear problem definition before starting the ideation process. One expert specifically mentioned his positive experiences of applying the value proposition designer, which, taken from the personal conversation, equals this methodology's value proposition canvas. The expert considers identifying the specific jobs-to-be-done, as well as the according consumer pains and gains, an essential step of facilitating the generation of valuable ideas afterwards. Referring to the implementation of an open innovation methodology, experts agree with the methodology concept of not integrating consumers into the steps of crystallizing and idea generating. The experts' opinion is also in line with the methodology's composition of intuitive and systematic creativity techniques. Brainstorming is considered an effective tool to open up thinking, activate creative thinking and strengthen the new mindset.

Following brainstorming with systematic creativity techniques, allows to direct the core group's thinking into certain directions. As presumed, this has proven to be especially useful for focusing, eliminating or extending ideas in managerial practice. While experts agree on brainstorming as an effective intuitive creativity technique, their recommendations on systematic creativity methods differ from the ones given in the methodology. As it is not possible to test the overall business model innovation within its eco-system, experts agree with the methodology's methodology on testing individual underlying assumptions of the methodology with minimum viable prototypes. Some experts particularly mention their positive experiences of utilizing 'minimum viable products'. The fact that consumers might struggle to recognize the overall innovation as such, further underlines the adequacy of creating several, specific prototypes to test individual assumptions. To gain solid knowledge, A/B-Tests and public or closed alpha/beta tests should be integrated into prototyping. Generally, the experts share the opinion that experiencing positive feedback from consumers during prototyping reinforces the new mindset and facilitates moving away from the dominant logic.

With regard to this methodology assessment, alterations and refinements can be derived. Consequently, Figure 10 depicts an overview of the methodology refinements deriving from the empirical research. A large version of the overall business methodology is illustrated in the Appendix Figure 11. 


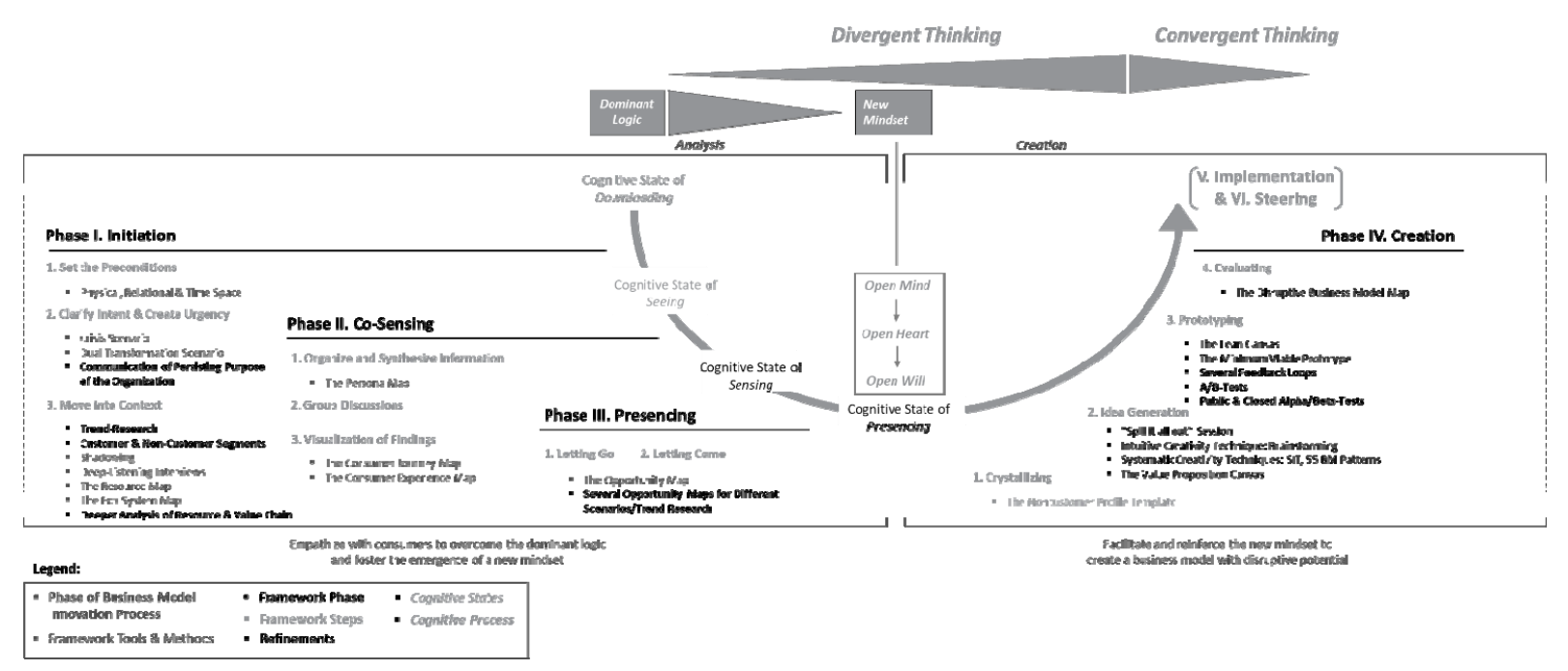

Figure 10. Refined Methodology for Generating a Business Model Innovation with Disruptive Potential based on Scharmer (n.d., pp. 6, 12)

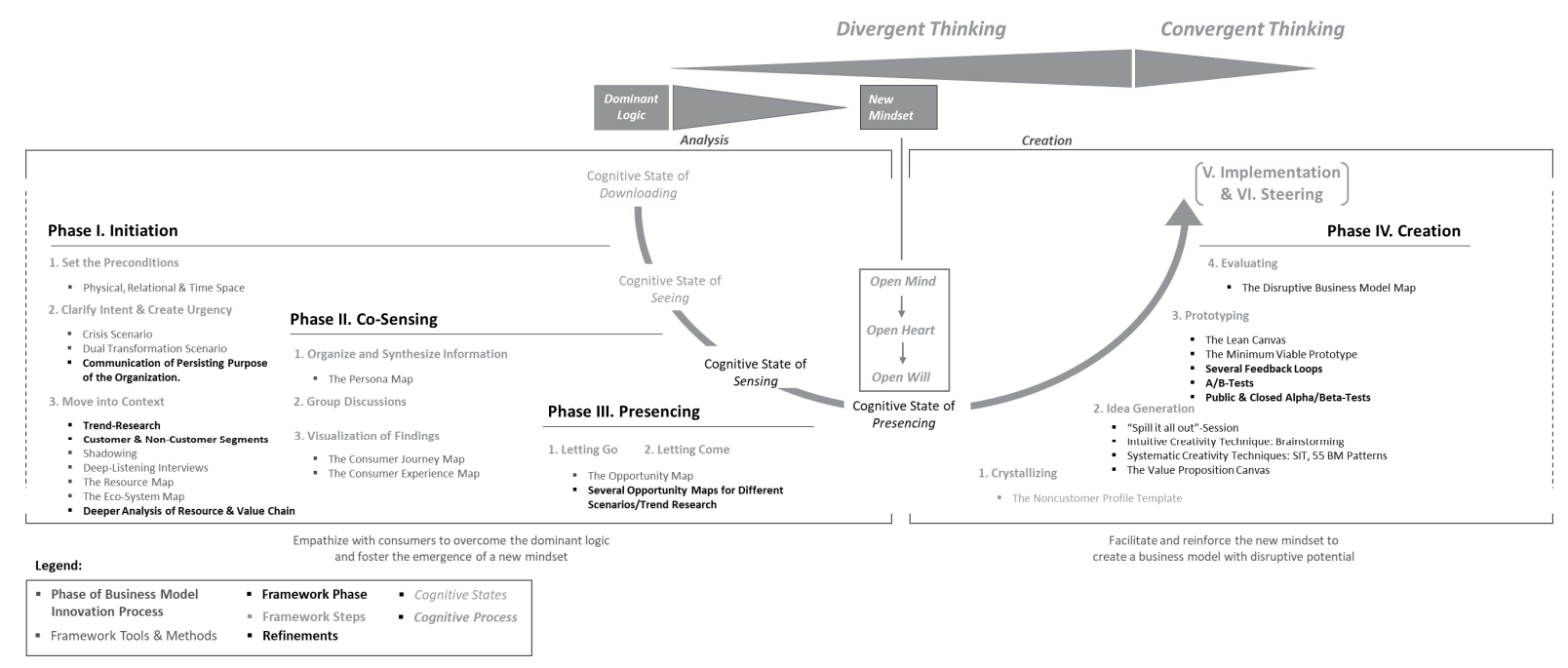

Figure 11. Large version of refined Methodology for Generating a Business Model Innovation with Disruptive Potential based on Scharmer (n.d., pp. 6, 12)

\section{References}

Anthony, S. D., Gilbert, C. G., \& Johnson, M. W. (2017). Dual Transformation. How to Reposition Today's Business While Creating the Future. Boston, MA: Harvard Business Review Press.

Amit, R., \& Zott, C. (2001). Value creation in e-business. Strategic Management Journal, (22), 493-520.

Bettis, R. A. (2000). The iron cage is emptying, the Dominant Logic no longer dominate. Advances in Strategic Management, 17, 167-174. 


\section{Ml Macrothink}

Journal of Entrepreneurship and Business Innovation

ISSN 2332-8851

2020, Vol. 7, No. 2

Bennett, N., \& Lemoine, G. J. (2001). What VUCA Really Means for You. Harvard Business Review, 92(1-2), 1-7.

Bettis, R. A., \& Prahalad, C. K. (1995). The Dominant Logic: Retrospective and Extension. Strategic Management Journal, 16(1), 5-14.

Bettis, R. A., Wong, Z., \& Blettner, D. (2011). Handbook of Organizational Learning and Knowledge Management. $2^{\text {nd }}$ Edition. Chichester, United Kingdom: John Wiley and Sons.

Bocken, N., Boons, F., \& Baldassarre, B. (2019). Sustainable business model experimentation by understanding ecologies of business models. Journal of Cleaner Production, 208, $1498-1512$.

Bouchikhi, H., \& Kimberly, J. R. (2003). Escaping the Identity. MIT Sloan Management Review, 44(3), 20-26.

Casadesus-Masanell, R., \& Ricart, J. E. (2009). From Strategy to Business Models and Tactics. Working Paper 813, Barcelona, Spain: IESE.

Casadesus-Masanell, R., \& Zhu, F. (2013). Business Model Innovation and Competitive Imitation: The Case of Sponsor-Based Business Models. Strategic Management Journal 34(4), 464-482.

Cavalcante, S. A., Kesting, P., \& Ulhoi, J. P. (2011). Business model dynamics and innovation: (Re-) establishing the missing linkages. Management Decision, 49(8), 1327-1342.

Chesbrough, H., \& Rosenbloom, R. S. (n.d.). The Role of the Business Model in Capturing Value from Innovation: Evidence from Xerox Corporation's Technology Spinoffs Company. Retrieved from https:/www.hbs.edu/faculty/Publication\%20Files/ 01-002_07351ae8-58be-44e5-a6d8-205cbf5b4424.pdf

Christensen, C. M., Raynor, M., \& McDonald, R. (2015). What is Disruptive Innovation? Harvard Business Review, 12(39), 44-53.

Comes, S., \& Berniker, L. (2008). Business Model Innovation. From Strategy to Execution Turning Accelerated Global Change into Opportunity (1st ed.). Berlin, Germany: Springer.

Csik, M. (2014). Patterns and the generation of ideas for business model innovations [in German: Muster und das Generieren von Ideen für Geschäftsmodellinnovationen]. Retrieved from http://www1.unisg.ch/www/edis.nsf/SysLkpByIdentifier/4263

Franke, T., \& Zu Knyphausen-Aufsess, D. (2014). On Dominant Logic: Review and Synthesis. Journal of Business Economics, 84(1), 27-70.

Gassmann, O., Frankenberger, K., \& Csik, M. (n.d.). The St. Gallen Business Model Navigator. https://doi.org/10.3139/9783446452848.fm

Gerstbach, I. (2017). 77 tools for design thinkers. Insider tips from the design thinking practice [in German: 77 Tools für Design Thinker. Insidertipps aus der DesignThinking-Praxis]. (1st ed.). Offenbach, Germany: GABAL.

Hacklin, F., \& Wallnöfer, M. (2012). The Business Model in the Practice of Strategic Decision Making: Insights from a Case Study. Management Decision, 50(2), 166-188. 
Holmes, F. (2017). Disrupt or Get Disrupted. Retrieved from https://www.forbes.com/sites/greatspeculations/2017/03/07/disrupt-or-getdisrupted/

Hopp, C., Antons, D., Kaminski, J., \& Salge, T. O. (2018). What 40 Years of Research Reveals about the Difference between Disruptive and Radical Innovation. Harvard Business Review Digital Articles. Retrieved from https://hbr.org/2018/04/what-40-years-of-research-reveals-about-the-difference-between-disr uptive-and-radical-innovation

Kotter, J. P. (2012). Leading Change. (1st ed.). Boston, MA: Harvard Business Review Press.

Kreutzer, R. (2018). Practice-oriented online marketing. Concepts - Instruments Checklists [in German: Praxisorientiertes Online-Marketing. Konzepte - Instrumente Checklisten]. (3rd ed.). Wiesbaden, Germany: Springer Gabler.

Lang, M. (2020). Business Model Innovation Methodologies: A Systematic Literature Review. Acta Universitatis Agriculturae et Silviculturae Mendelianae Brunensis, 68(2), 435-449.

Liedtka, J., \& Ogilvie, T. (2011). Designing for Growth: A Design Thinking Toolkit for Managers (1st ed.). New York, NY: Columbia University Press.

Lindgardt, Z., Reeves, M., Stalk, G. et al. (2009). Business Model Innovation: when the game gets tough change the game. Munich, Germany: The Boston Consulting Group.

Magretta, J. (2002). Why Business Models Matter. Harvard Business Review, 1-15.

Maurya, A. (2012). Running Lean. Iterate from Plan A to a Plan That Works. (2nd ed.). Bejing, China: O’Reilly.

Matzler, K., Bailom, F., Friedrich Von Den Eichen et al. (2016). Digital Disruption. How to prepare your company for the digital age [in German: Digital Disruption. Wie Sie Ihr Unternehmen auf das digitale Zeitalter vorbereiten]. Munich, Germany: Vahlen.

Mitchell, D., \& Coles, C. (2003). The ultimate competitive advantage of continuing business model innovation. Journal of Business Strategy, 24, 15-21.

Mitchell, D., \& Coles, C. (2004). Business model innovation breakthrough moves. Journal of Business Strategy, 25, 16-26.

Moore, G. A. (2006). Dealing with Darwin: How Great Companies Innovate at Every Phase of Their Evolution. (1st ed., pp. 17-42). Chichester, United Kingdom: Capstone Publishing.

Moreno, H. (2017). Reinventing Business Models In A Disruptive World. Retrieved from https://www.forbes.com/sites/forbesinsights/2017/03/02/reinventingbusiness-models-in-a-disr uptive-world/

Oskam, J., \& Boswijk, A. (2016). Airbnb: The Future of Networked Hospitality Businesses. Journal of Tourism Futures, 1(2), 22-42.

Osterwalder, A. (2004). The Business Model Ontology: A proposition in a design science methodology. Doctoral dissertation. Lausanne, Switzerland: University of Lausanne 


\section{Macrothink}

Journal of Entrepreneurship and Business Innovation

ISSN 2332-8851

2020, Vol. 7, No. 2

Osterwalder, A., \& Pigneur, Y. (2010). Business Model Generation. New Jersey, NJ: John Wiley and Sons.

Osterwalder, A., Pigneur, Y., Bernarda, G., \& Smith, A. (2014). Value Proposition Design. How to Create Products and Services Customers Want (1st ed.). Hoboken, NJ: Wiley.

Randles, S., Laasch, O. (2016). Theorising the normative business model. Organisational Environment, 29, 53-73.

Rogers, D. L. (2016). The digital transformation playbook. Rethink your business for the digital age. New York, NY: Columbia University Press.

Rosa, M., Marques, C. A. N., \& Rozenfeld, H. (2017). Commonalities and particularities of design process and design thinking. Procedia CIRP, 64, 253-258.

Schallmo, D. (2013). Business model innovation. Basics, existing methodologies, methodical procedure and B2B business models [in German: Geschäftsmodell-Innovation. Grundlagen, Bestehende Ansätze, Methodisches Vorgehen und B2B Geschäftsmodelle]. (1st ed.) Wiesbaden, Germany: Springer Gabler.

Scharmer, O. C. (2016). Theory U: Leading from the Future as It Emerges (2nd ed.). Oakland, CA: Berrett-Koehler Publishers.

Scharmer, O. C. (n.d). Addressing the Blind Spot of Our Time. An Executive Summary of the New Book by Otto Scharmer Theory U: Leading from the Future as It Emerges. Retrieved from

https://solonline.org/wp-content/uploads/2016/12/Exec_Summary_Sept19-Theory-U-leadingfrom-the-emerging-future-copy.pdf

Shapiro, A. (2020). Netflix Stock Hits Record High, Is Now Worth More Than Disney. Retrieved from https://www.forbes.com/sites/dbloom/2018/05/26/netflix-disney-comcast-market-capitalizatio n-valuation/

Shafer, S. M., Smith, H. J., \& Linder, J. (2004). The Power of Business Models. Business Horizons, (48), 199-207.

Sniukas, M., Parker, L., \& Morasky, M. (2016). The Art of Opportunity (1st ed.). Hoboken, NJ: John Wiley\&Sons.

Skarzynski, P., \& Gibson, R. (2008). Innovation to the core: a blueprint for transforming the way your company. Boston, MA: Harvard Business Press.

Stampfl, G. (2016). The Process of Business Model Innovation: An Empirical Exploration. (1st ed.). Wiesbaden, Germany: Springer Gabler.

Tendayi, V., Toma, D., \& Gons, E. (2017). The Corporate Startup. How Established Companies Can Develop Successful Innovation Ecosystems (1st ed.). Deventer, Netherlands: Vakmedianet.

Tikkanen, H., Lamberg, J. A., \& Parvinen, P. (2005). Managerial cognition, action and the business model of the firm. Management Decision, 43(6), 789-809. 


\section{Macrothink}

Tovstiga, G., \& Birchall, D. W. (2014). Capturing Opportunity in Disruption: Strategic Capabilities and Organization Factors. Retrieved from https://warwick.ac.uk/fac/soc/wbs/conf/olkc/archive/oklc5/papers/a-3_tovstiga.pdf

UȚĂ, I. C. (2020). 8 Key Factors Behind Netflix's Success Story. Retrieved from https://brandminds.live/8-key-factors-behind-netflixs-success-story/.

Vianna, M., Vianna, Y., Adler, I. K., Lucena, B., \& Russo, B. (2014). Design Thinking. Innovation in the company [in German: Design Thinking. Innovation im Unternehmen].(1st ed.). Berlin, Germany: Logos Verlag.

Wirtz, B. (2010). Business Model Management. (1st ed.). Wiesbaden, Germany: Gabler.

Weiner, N., Renner, T., \& Kett, H. (2010). Business models in the Internet of Services; current status in research and practice [in German: Geschäftsmodelle im Internet der Dienste; Aktueller Stand in Forschung und Praxis]. Stuttgart, Germany: Frauenhofer Institut für Arbeitswirtschaft und Organisation IAO.

Wördenweber, B., Eggert, M., \& Schmitt, M. (2012). Behaviour-oriented innovation management. Activate entrepreneurial potential [in German: Verhaltensorientiertes Innovationsmanagement. Unternehmerisches Potenzial Aktivieren]. (1st ed.). Heidelberg, Germany: Springer.

Zervas, G., Proserpio, D., \& Byers, J. W. (2016). The Rise of the Sharing Economy: Estimating the Impact of Airbnb on the Hotel Industry. Retrieved from http://people.bu.edu/zg/publications/airbnb.pdf

\section{Notes}

Note 1. The aim is to enhance the organization's sensitivity to environmental changes by creating a worst-case scenario, named crisis scenario (Prahalad\&Bettis, 2000, p. 137).

Note 2. The dual transformation scenario (Anthony, Gilbert, \& Johnson, 2017, p. 16). The tool premises that two types of transformation are required for established companies to successfully deal with disruption. One the one hand, the scenario covers the repositioning and stabilizing of the core business. On the other hand, a second transformation focuses on growing new business in parallel.

Note 3. Reframing means the reinterpretation of an incident into a new reference frame (Wördenweber, Eggert, \& Schmitt, 2012, p. 52).

\section{Copyrights}

Copyright for this article is retained by the author(s), with first publication rights granted to the journal.

This is an open-access article distributed under the terms and conditions of the Creative Commons Attribution license (http://creativecommons.org/licenses/by/4.0/) 